\title{
Assessing Startup Performance: "Case Study at National Business Incubator"
}

\author{
Mayar Soeryo Prayogo ${ }^{1 *}$, Usep Suhud ${ }^{2}$, Agung Wahyu Handaru \\ ${ }^{1,2,3}$ Universitas Negeri Jakarta Jakarta, Indonesia \\ email: ${ }^{* 1}$ msprayogo@gmail.com; ${ }^{2}$ usuhud@unj.ac.id; ${ }^{3}$ ahandaru@unj.ac.id
}

\begin{abstract}
This study aims to examine the Startup Performance of the national incubator which are includes Knowledge Management, Business Incubator, and the effectiveness of innovation. Besides that this research is expected to have tangible benefits toward the process of achieving Startup goals that owned by business performers. This study will test five hypotheses of direct influence (effect) and two hypotheses of mediating influence (indirect effect). This study will use 339 respondents as sample with a Startup analysis unit that operates and is affiliated with a local Startup development business incubator located in Jabodetabek, West Java Province (excluding Depok \& Bekasi), Central Java and Bali. The intended startup on this research is Person In Charge (PIC) / company founder / owner. The PIC / founder / owner of the company here is not limited by age, gender and position at the Startup. The company's PIC / founder / owner is only limited towardStartup which is built by the business incubator. The research method used is Confirmatory Factor Analysis (CFA) to test path analysis by operating AMOS 22. The results of this study indicate that all proposed hypotheses can be accepted statistically, both direct side and indirect effects (mediation) side
\end{abstract}

Keywords - Startup Performance, Knowledge Management, Incubator Business, Innovation Effectivity, confirmatory factor analysis (CFA), AMOS22

\section{INTRODUCTION}

The growth and development of Startup is one of the focus of the JokowiJK Government program through the growth of startup businesses (creative people) along the value chain at the stages of creation, production, distribution, consumption and conservation, where the creative economic strength is more dependent on the excellence of human resources through creative ideas of human thought as stated in Nawacita 2015-2019, where 1000 Technopreneur and Nexticorn (Next Indonesia Unicorn) became one of the main programs.

CB Insight in its report in 2019 noted that there are currently more than 300 unicorns around the world, where there are 4 (four) Indonesian companies that have become Global Unicorn Club, namely Traveloka (Travel Technology), Bukalapak and Tokopedia (E-commerce) as well as Go-Jek (On Demand). The term Startup level was originally coined by Lee (2013) who used the term unicorn to refer to Startup worth 1 billion US dollars. The 
Startup level phases which show 'class', are currently developing from Cockroach (newly pioneered startup), Ponies (valuation of US \$ 10 Million), Centarurs (valuation of US \$ 100 Million), Unicorn (valuation of US \$ 1 billion), to Decacorn (valuation of US \$ 10 Million), Centarurs(valuation of US \$ 100 Million), Unicorn (valuation of US \$ 1 billion), to Decacorn (valuation of US \$ 10 Million) valuation of US \$ 10 billion).

One of the challenges of Startups that is based on creative ideas is still weak competitiveness, which refers to the results of the 2015 Martin Prosperity Institute Global Creativity Index (GCI) survey, Indonesia is one of the countries that is not yet creative. Based on the survey results, Indonesia ranks 115 out of 139 countries. Indonesia's position is far below that of neighboring countries such as Singapore (9), Malaysia (63), and Vietnam (80). GCI is calculated using three factors, namely technology (technology), creative people (talent), and tolerance (tolerance). Startup is a new company that strives for existence. Startup entities are largely formed based on bright ideas and grow to succeed through the stages of bootstarpping stage, seed stage, and creation stage [1].

Startup Performance in the Technology-Based Starter Company (PPBT) program conducted by the Ministry of Research, Technology and Higher Education is measured by indicators of production performance, marketing performance, finance performance, and performance personnel. Performance problems are illustrated by not achieving the target indicators set at the Startup under the guidance of the Semarang Telematics Creation and Innovation Incubator (IKITAS). Performance problems also occur at Startups located in Bandung Techno Park (BTP), namely Melisa.id with Point of Sales / POS Application products (POS applications integrated with chat systems), Cross Variety Control that produces EGGQ products (egg quality detection devices image processing-based domestic chickens), RasturaAyuGayo with Atmatsya products (natural preservative liquid fish preservatives that are safe for consumption), AgramaultInvestama with ProMix Agri-Biotech products (Fertilizers that use six microbial protagonists that function as an accelerator for faster composting time) that does not reach the target on sales (marketing performance / sales turnover) and production targets (production performance).

One of the phenomena of startup failure in Indonesia occurred in 2016, where there were several startups that failed, including foodfanda, YESBOSS, Diana, Shopious, Jade, Coral, ensogo, rakuten, and OpenRice due to products and services that were not competitive. Startups that are not able to produce products and services will be automatically excluded from competition by competitors. Startup Performance is influenced by innovation, where in the competitive era, the implementation of innovation plays an important role in dealing with very rapid changes in the tastes and preferences of customers from the market to create products and services in accordance with market demands. Innovation is defined as the process of creating new knowledge and ideas so as to produce different ways, processes,

IJoASER,Volume 2,Issue 3, November,2019

DOI: 10.33648/ijoaser.v2i2.40

Copyriht: STAI AI-Furqan Makassar,Indonesia

Content License: CC-BY-SA 
structures and technologies that are better for producing products and services in accordance with customer needs and preferences [2].

Then the implementation of Knowledge Management at Startup has a significant effect on improving performance through a positive contribution to sustainable startup growth by increasing financial, environmental, human, market, organizational, relational, technical and technological performance [3]. Startup performance is influenced by the Startup ecosystem that has not been fully developed, where the Startup ecosystem will form Knowledge Management as an enabler in innovation by creating, storing, transferring, and applying knowledge. Based on a survey conducted by CBI Insight on the founder of a poor company, Startup Team is one of the 5 main causes of startup failure. BTP as a business incubator identifies a bad team as a result of Knowledge Management not running optimally because Startups only rely on facilitation from business incubators that provide business coaching to increase business capacity (scale up).

Business incubators are effective tools to accelerate the growth of startups through clustering opportunities, business support services, networking opportunities and space incubators [4]. Business incubators play an important role in supporting startups who are most at risk of failure during the founding phase. This was conveyed by PasarLaut.com (one of BTP's business incubation startups), where in starting the initial step in creating an online sea product trading portal, it received support from business incubators to sustain in the form of supporting funding, physical infrastructure support, legal support administration and networking support. However, business incubators are considered to be still lacking in facilitating access to capital, in the form of an effort to bring investors together to finance business (business matching) and market access to help market products that have been produced by startups. The business incubator acts as an innovation ecosystem for startup growth and development. Weak business incubator seen in the business incubation data at BTP shows the number of incubation tenants who passed during the period of 2015 to 2017 is very minimal, in 2015 none of the Startup tenants passed, whereas in 2016 only 2 (two) and 8 (eight) Startup tenants in 2017 who passed from 21 (twenty one) who were scouted.

In the context of developing MSMEs conducted by Bank Indonesia, the Business incubator study states that the Business incubator needs infrastructure support, namely soft infrastructure and hard infrastructure. Based on observations made at the Technical Implementation Unit (UPT) of the Incubator Business Center (IBC) Semarang that foster 12 (twelve) tenants / startups, especially those located in Semarang, show that coworking space and supporting facilities and infrastructure require improvements to support the growth and development of startups. . In addition, facilitation of assistance, guidance, training, facilitation of product development and access to financial and marketing institutions provided to startups is still constrained by the lack of local government budgets as responsible for the business incubator. The above is marked by the phenomenon of the number of incubation tenants who passed during the 2015 - 2017 period at BTP was very minimal compared to the tenants who were fostered. Based on the Technology Business Incubation Services Report that has been conducted at 
KST, the number of tenants who passed to BTP during the period 2015 2017 only 10 tenants out of 21 tenants were fostered. This research will conduct an in-depth study of the analysis of Startup Performance in the national incubator.

\section{METHOD}

The sample of this study is the population in the Jakarta area with an age range of less than 18 years to more than 55 years that is easily found by researchers and in accordance with the research criteria, application users calling the application online. Measurement statements in the questionnaire are measured using a Likert scale with a scale of 1-7. This study uses the Structural Equation Modeling (SEM) analysis method, a multivariate technique that combines aspects of multiple regression and factor analysis to estimate correlations that are interdependent Meanwhile, conclude several definitions that SEM has characteristics that are as analytical techniques that function to be more asserting than explaining.SEM is a multivariate technique that functions to combine aspects of multiple regression and factor analysis to estimate the interdependence relationship between variables used in the research model simultaneously [5].

SEM is a second generation multivariate analysis technique that combines factor analysis with path analysis, thus enabling researchers to test and estimate simultaneously (together) the relationship between multiple latent independent variables and multiple latent dependent variables with many indicators. Meanwhile, according to Santoso (2018), SEM is an increasingly popular statistical analysis tool which is a combination of factor analysis and regression analysis. SEM has the ability to measure latent variables that are not directly measured but through the estimation of indicators or parameters.

Unit of analysis for this research is a Startup that operates and is affiliated with a local Startup development business incubator located in Jabodetabek, West Java Province (excluding Depok \& Bekasi), Central Java and Bali. The intended startup is Person In Charge (PIC) / company founder / owner. The $\mathrm{PIC} /$ founder / owner of the company here is not limited by age, gender and position at the Startup. The company's PIC / founder / owner is only limited to Startup, which is built by the business incubator. This research will be carried out in a local Startup development business incubator located in Greater Jakarta, West Java Province (excluding Depok \& Bekasi), Central Java and Bali.

This study uses quantitative methods and the technique of this study is a survey, using a questionnaire instrument. In this study using primary data. The method used in collecting primary data is done through a questionnaire

IJoASER,Volume 2,Issue 3, November,2019

DOI: 10.33648/ijoaser.v2i2.40

Copyriht: STAI Al-Furqan Makassar,Indonesia

Content License: CC-BY-SA 
or questionnaire method to obtain data about the dimensions of the construct being developed using a 1-5 item Likert scale. Dimension data of the variables analyzed in this study will be given to respondents using a scale of 1-5 obtaining interval data. Comprehensive analysis of all variables in the research at the multivariate analysis stage was carried out by modeling the SEM structural equation. In general SEM analysis techniques according to Ghozali (2014) can be divided into 2 main characteristics: 1) estimation of multiple interdependence relationships of many variables; 2) the ability to present unobserved concepts in these relationships by involving measures of error in the estimation process then connecting between construct variables through a system of simultaneous equations. Estimates of model parameters use maximum likelihood estimates. SEM is a multivariate technique that functions to combine aspects of multiple regression and factor analysis to estimate the interdependence relationship between variables used in the research model simultaneously [6].

This study uses the Structural Equation Modeling (SEM) analysis method, which is a multivariate technique that combines aspects of multiple regression and factor analysis to estimate correlations that are interdependent simultaneously [7]. conclude several definitions that SEM has characteristics that are as analytical techniques that function to be more asserting than explaining [8]. SEM is a second generation multivariate analysis technique that combines factor analysis with path analysis, allowing researchers to test and estimate simultaneously (together) the relationship between multiple latent independent variables and multiple latent dependent variables with many indicators [9]. Meanwhile SEM is an increasingly popular statistical analysis tool which is a combination of factor analysis and regression analysis [10]. SEM has the ability to measure latent variables that are not directly measured but through the estimation of indicators or parameters [11].

\section{RESUlTS AND DISCUSSION}

This research was conducted on technology-based startups engaged in eight focus areas, namely: food, health and medicine, energy, transportation, information and communication technology, defense and security, raw materials, and advanced materials located in Jabodetabek, West Java Province (not included Depok \& Bekasi), Central Java and Bali. The amount number of samples was taken was 302 respondents who were Person In Charge (PIC) / founder / owner at startups affiliated with business incubators. The profile of these respondents is scattered with various demographic criteria which are described in table 2 below.

Table 2. Demographic Profile of Respondents

\begin{tabular}{|c|l|c|r|}
\hline Criteria & \multicolumn{1}{|c|}{ Group } & Frequency & Persentage \\
\hline position of respondent & Founder & 147 & $48,68 \%$ \\
\hline
\end{tabular}

International Journal on Advanced Science, Education, and Religion (IJoASER) 


\begin{tabular}{|c|c|c|c|}
\hline & Owner & 140 & $46,36 \%$ \\
\hline & Manager & 12 & $3,97 \%$ \\
\hline & Etc & 3 & $0,99 \%$ \\
\hline \multirow{9}{*}{ Startup Field } & Food & 9 & $2,98 \%$ \\
\hline & Healthy and Medicine & 1 & $0,33 \%$ \\
\hline & Energy & 0 & $0,00 \%$ \\
\hline & Transportation & 2 & $0,66 \%$ \\
\hline & Teknologi Informasi dan Komunikasi (ICT) & 270 & $89,40 \%$ \\
\hline & Security and defense & 0 & $0,00 \%$ \\
\hline & Raw Material & 1 & $0,33 \%$ \\
\hline & Advanced Material & 2 & $0,66 \%$ \\
\hline & Etc (Tourism) & 17 & $5,63 \%$ \\
\hline \multirow{5}{*}{ Domicile } & Jabodetabek & 162 & $53,64 \%$ \\
\hline & Jawa Tengah & 60 & $19,87 \%$ \\
\hline & $\begin{array}{l}\text { Jawa Barat (Diluar Bogor, Depok, Dan } \\
\text { Bekasi) }\end{array}$ & 42 & $13,91 \%$ \\
\hline & Bali Dan NTB & 25 & $8,28 \%$ \\
\hline & Wilayah Lainnya & 13 & $4,31 \%$ \\
\hline \multirow{5}{*}{ Age } & $18-23$ & 17 & $5,63 \%$ \\
\hline & $24-29$ & 160 & $52,98 \%$ \\
\hline & $30-35$ & 113 & $37,42 \%$ \\
\hline & $36-41$ & 9 & $2,98 \%$ \\
\hline & $>41$ & 3 & $0,99 \%$ \\
\hline \multirow[b]{2}{*}{ Sex } & Man & 222 & $73,51 \%$ \\
\hline & Women & 80 & $26,49 \%$ \\
\hline \multirow{6}{*}{ Education } & $<$ SLTA & 1 & $0,33 \%$ \\
\hline & SLTA & 6 & $1,99 \%$ \\
\hline & Diploma & 38 & $12,58 \%$ \\
\hline & S1 & 215 & $71,19 \%$ \\
\hline & S2 & 42 & $13,91 \%$ \\
\hline & S3 & 0 & $0,00 \%$ \\
\hline \multirow{2}{*}{$\begin{array}{l}\text { Expected on role of } \\
\text { government }\end{array}$} & Market Access & 77 & $25,50 \%$ \\
\hline & Infrastructure Facilitation & 114 & $37,75 \%$ \\
\hline
\end{tabular}

IJoASER,Volume 2,Issue 3, November,2019

DOI: 10.33648/ijoaser.v2i2.40

Copyriht: STAI Al-Furqan Makassar,Indonesia

Content License: CC-BY-SA 


\begin{tabular}{|l|c|r|} 
Capital Facilitation & 20 & $6,62 \%$ \\
\hline Regulations and Laws & 4 & $1,33 \%$ \\
\hline Human Resources Development & 85 & $28,15 \%$ \\
\hline Inexpextation & 2 & $0,66 \%$ \\
\hline
\end{tabular}

Source: Processed by Researcher, (2019)

Based on the prerequisite tests conducted to test the indicators used in the research model, the results obtained are all the indicators used to test the model meet the required criteria. The research model has fulfilled the normality requirements through testing using critical ratio skewness criteria. The results of the normality test showed that the research data had normal distribution because the value of cr skewness and univariate kurtosis of all indicators were in the interval of $-2.58<\mathrm{z}<2.58$ as well as the multivariate $\mathrm{cr}$ value of 2.311 indicating that the multivariate $\mathrm{cr}$ had been in the interval $2.58<\mathrm{z}<2.58$.

Reliability test using the AVE and CR values based on the test results on the indicator instrument shows the AVE value is equal to 0.5 and the CR value has exceeded 0.7 which means that overall it has fulfilled validity and has been reliable. Thus, the analysis process can be continued at the next stage, which is the prerequisite test phase of SEM analysis. Then the results of testing the validity using the EFA showed no cross loading between indicator items in the tested variable, besides that the EFA test results showed that no pattern matrix was formed. This shows that the tested indicator items can be tested at a later stage.

CFA model depicted in Figure 2 has been modified. Modifications are made by eliminating the indicator items on the model. Modifications were made so that all the criteria in goodness of fit were met as it was seen that the CFA model could be further analyzed because it had a probability score (P) greater than 0.05 which was 0.084 and the score in the goodness of fit criteria had been met. The next process is to create a path analysis model. Then in the next process in the results of Figure 3 there is a proposed hypothesis model that meets the goodness of fit $(\mathrm{GoF})$ criteria with a probability value of 0.19 and all GoF criteria have been met. This makes hypothesis testing can be done with the model that has been made. 


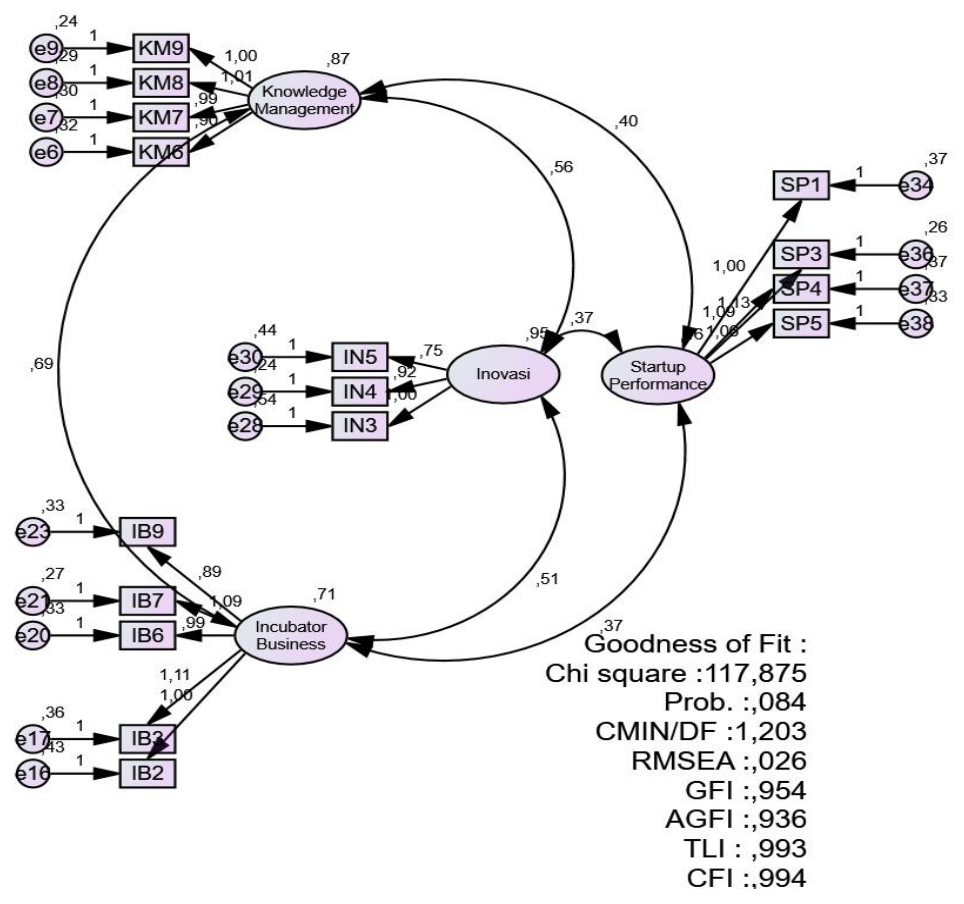

Figure 2.Confirmatory Factor Analysis Covarians

Hypothesis suitability test is done by looking at the t-value, which is the value of the critical ratio (CR) in the regression weight with the provisions if the value is $\geq 1.96$, then the research hypothesis is accepted with a probability value of 0.05 or with a sign that indicates the value of $* * *$ less than 0.01 or close to zero. Meanwhile, for testing H6 and H7, the indirect effect will be tested through mediating variables using AMOS output by looking at scores on indirect effects.

After testing the model, the next step is to look at the regression weight value to find out whether the tested hypothesis is accepted or not. In table 3 there are the results of calculations from the hypothesis test which states the relationship between the variables tested. In the results of these calculations stated that all hypotheses tested were accepted. Because it shows the value of the critical ratio which is above 1.96 and the probability value $(\mathrm{P})$ which is below 0.05 as in table 3 below

After testing the model, the next step is to look at the regression weight value to find out whether the tested hypothesis is accepted or not. In table 3 there are the results of calculations from the hypothesis test which states the relationship between the variables tested. In the results of these calculations stated that all hypotheses tested were accepted. Because it shows the value of 
the critical ratio which is above 1.96 and the probability value $(\mathrm{P})$ which is below 0.05 as in table 3 below.

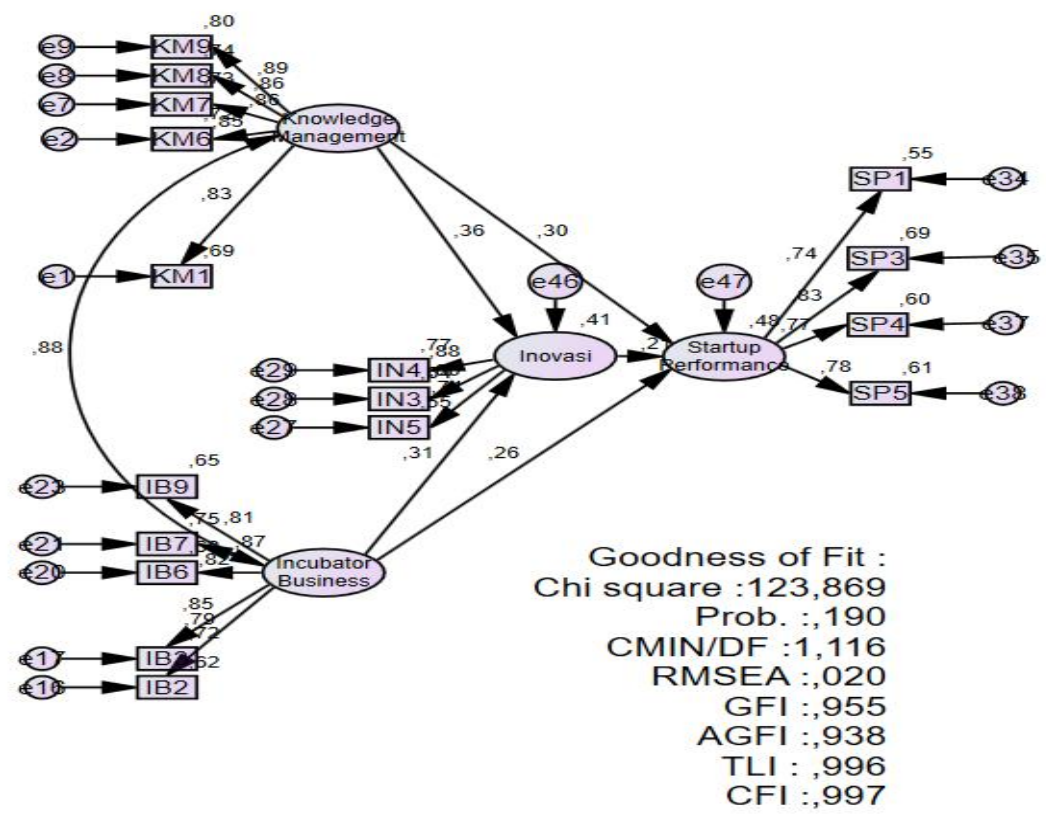

Figure3.Research model in the path diagram

Tabel 3. Regression Weight Model

\begin{tabular}{|c|c|c|c|c|c|c|c|}
\hline & & & Estimate & S.E. & C.R. & $\mathrm{P}$ & Label \\
\hline \multirow{3}{*}{ IN } & \multirow{3}{*}{$<---$} & \multirow{3}{*}{ KM } & \multirow{3}{*}{0.3} & 0.11 & 2.70 & 0.00 & \multirow{3}{*}{ par_13 } \\
\hline & & & & 1 & 8 & 7 & \\
\hline & & & & 0.11 & 2.32 & 0.02 & \\
\hline \multirow[t]{2}{*}{ IN } & \multirow[t]{2}{*}{$<---$} & \multirow[t]{2}{*}{ IB } & \multirow[t]{2}{*}{0.267} & 5 & 2 & 0 & \multirow{2}{*}{ par_14 } \\
\hline & & & & 0.09 & 2.36 & 0.01 & \\
\hline \multirow[t]{2}{*}{ SP } & \multirow[t]{2}{*}{$<---$} & \multirow[t]{2}{*}{ KM } & \multirow[t]{2}{*}{0.234} & 9 & 4 & 8 & \multirow[t]{2}{*}{ par_15 } \\
\hline & & & & 0.10 & 2.04 & 0.04 & \\
\hline \multirow[t]{2}{*}{ SP } & \multirow[t]{2}{*}{$<---$} & \multirow[t]{2}{*}{ IB } & \multirow[t]{2}{*}{0.209} & 2 & 6 & 1 & \multirow[t]{2}{*}{ par_16 } \\
\hline & & & & 0.06 & 2.85 & 0.00 & \\
\hline SP & $<---$ & IN & 0.192 & 7 & 5 & 4 & par_17 \\
\hline
\end{tabular}

Source: SEM AMOS Data Processing Software (2019).

The $\mathrm{p}$ value of the influence of the variable Knowledge Management $(\mathrm{KM})$ on the effectiveness of innovation $(\mathrm{KM} \rightarrow \mathrm{IN})$ is significant ( $\mathrm{p}$ value $=$ 0.007 ) with cr having a positive sign of 2,708 . Because the $p$ value obtained $<0.05$ and $\mathrm{cr}$ is positive $>1.96$, Ho is rejected and it is concluded that Knowledge Management (KM) has a positive and significant effect on the effectiveness of innovation, this indicates that the higher Knowledge Management (KM) then the higher the effectiveness of innovation, and on 
contrary. The results of the hypothesis test are in accordance with research conducted by Plessis [12] and Akram [2] which states that there is an influence between Knowledge Management on the Effectiveness of Innovation.

The $p$ value of the influence of the Incubator Business (IB) variable on the effectiveness of innovation $(\mathrm{IB} \rightarrow \mathrm{IN})$ is significant $(\mathrm{p}$ value $=0.020$ ) with a positive cr marking of 2,322. Because the $\mathrm{p}$ value obtained $<0.05$ and $\mathrm{cr}$ is positive $>1.96$, Ho is rejected and it is concluded that the Incubator Business (IB) has a positive and significant effect on the effectiveness of innovation, this indicates that the higher the Incubator Business (IB) then the higher the effectiveness of innovation too, and on contrary. The results of the hypothesis test are in accordance with research conducted by Allahar et.al (2016) which in his research concluded that business incubation shows the potential for innovation development in business. Then in Menon et.al (2007) states that business incubation is an institutional institution that develops an atmosphere for innovation and the creation of a startup through the establishment of a network of active interactions between academia, industry, and government in order to create a liquid situation for sharing ideas, knowledge, experience and facilities and the development of new technologies.

The $p$ value of the influence of the Knowledge Management (KM) variable on Startup Performance $(\mathrm{SP})(\mathrm{KM} \rightarrow \mathrm{SP})$ is significant ( $\mathrm{p}$ value $=$ 0.018 ) with a positive cr marking of 2,364 . Because the $p$ value obtained $<0.05$ and $\mathrm{cr}$ is positive $>1.96$, Ho is rejected and it is concluded that Knowledge Management (KM) has a positive and significant effect on Startup Performance (SP), this indicates that the higher Knowledge Management ( KM), will make higher the Startup Performance (SP) too, and on contrary. The results of the hypothesis test are in accordance with research conducted by Studies conducted by Imamoglu et.al [13] which in his research explores the relationship between organizational learning (organizational learning), TQM (Total Quality Management), and innovation with Firm Performance, where research results shows that these variables have a positive relationship with company performance. Then Rofiaty et.al (2015) states that the effect of Knowledge Management directly on organizational performance is less than the effect on organizational performance mediated by strategy implementation.

The $p$ value of the effect of the Incubator Business (IB) variable on Startup Performance $(\mathrm{SP})$ is very significant $(\mathrm{p}$ value $=0.041)$ with a positive cr of 2.046. Because the $\mathrm{p}$ value obtained $<0.05$ and $\mathrm{cr}$ is positive $>1.96$, Ho is rejected and it is concluded that Incubator Business (IB) has a positive and significant effect on Startup Performance (SP), this statement indicates that the higher Incubator Business (IB), will make higher the Startup Performance (SP) too, and on contrary so on. The results of the hypothesis test are in accordance with research conducted by Studies conducted by Laskar et.al (2016) showing that business incubators play a role in supporting performance by avoiding and minimizing the risk of failure through

IJoASER,Volume 2,Issue 3, November,2019

DOI: 10.33648/ijoaser.v2i2.40

Copyriht: STAI Al-Furqan Makassar,Indonesia

Content License: CC-BY-SA 
clustering opportunities, business support services, networking opportunities and incubator space. Then research conducted by Dutta [14] concluded that business incubators can help in the growth and development of a business startup.

The value of $p$ value of the effect of the Innovation Effectiveness (IN) variable on the company against Startup Performance (SP) (IN $\rightarrow$ SP) is very significant ( $\mathrm{p}$ value $=0.004$ ) with a positive cr marking of 2,855 . Because the $\mathrm{p}$ value obtained $<0.05$ and $\mathrm{cr}$ is positive $>1.96$, Ho is rejected and it is concluded that the Effectiveness of Innovation has a positive and significant effect on Startup Performance (SP), this shows that the higher the Effectiveness of Innovation (IN) will make the higher the Startup Performance (SP) too, and on contrary so on. The results of the hypothesis test are in accordance with research conducted by the Study conducted by and who found a positive relationship between innovation and family company performance. This is supported by research conducted by Price et.al showing strong support for innovation in family and non-family companies.

In this study, the mediation test Innovation variable (IN) which acts as a mediating variable / intervening on the indirect effect of Knowledge Management (KM) and Incubator Business (IB) variables on Startup Performance (SP) uses a large value of direct and indirect influence. For the large value of direct and indirect effects can be seen in the following table:

Table 4. Standardized Direct Effects (Group number 1 - Default model)

\begin{tabular}{|c|c|c|c|}
\hline & IB & KM & IN \\
\hline IN & 0.307 & 0.356 & 0 \\
\hline SP & 0.260 & 0.300 & 0.208 \\
\hline
\end{tabular}

Standardized Indirect Effects (Group number 1 - Default model)

\begin{tabular}{|r|r|r|r|}
\hline & IB & KM & IN \\
\hline IN & 0.000 & 0.000 & 0.000 \\
\hline SP & 0.064 & 0.074 & 0.000 \\
\hline
\end{tabular}

Source: SEM AMOS Data Processing Software (2019).

Furthermore, the Knowledge Management (KM) variable, based on the table above, can be seen that the direct influence of Knowledge Management (KM) on Startup Performance (SP) is 0.300 , while the indirect effect of Knowledge Management (KM) on Startup Performance (SP) mediated by the innovation variable is 0.074 . This shows that the magnitude of the indirect effect is lower than the magnitude of the direct effect, this indicates the role of the innovation variable in mediating the indirect effect of the Knowledge Management (KM) variable on Startup Performance (SP).

Based on the table above, it can be seen that the direct effect of the Incubator Business (IB) variable on Startup Performance (SP) is 0.260 , while the indirect effect of the Incubator Business (IB) variable on the Startup Performance (SP) mediated by the engagement variable is of 0.064 . This 
shows that the magnitude of the indirect effect is lower than the magnitude of the direct effect, this indicates the role of the innovation variable in mediating the indirect effect of the Incubator Business (IB) variable on Startup Performance (SP).

\section{CONCLUSION}

Based on the results of data processing and analysis of the entire research data, the conclusion that can be obtained is that all hypotheses tested can be accepted. Knowledge Management Variable (KM) has a positive and significant effect on the Effectiveness of Innovation (IN). Based on this it can be concluded that, this shows that if Knowledge Management (KM) is increasing, it will increase the Effectiveness of Innovation (IN), and vice versa. The Incubator Business (IB) variable has a positive and significant effect on the Effectiveness of Innovation (IN). Based on this it can be concluded that, this shows that if the Incubator Business (IB) available performs their functions properly. the better the business incubator, the better the Effectiveness of Innovation (IN). Besides that, the Incubator Business (IB) variable has a positive and significant effect on the Effectiveness of Innovation (IN). Based on this it can be concluded that, this shows that if the Incubator Business (IB) available performs their functions properly. the better the business incubator, the more effective the business actors will be in innovating and vice versa. Variable Effectiveness Innovation (IN) has a positive and significant effect on Startup Performance (SP). Based on this it can be concluded that, this shows that if the Effectiveness of Innovation (IN) in the available startup companies perform their functions properly. the better the business incubator, the more will increase Startup Performance (SP), and vice versa. Based on the hypothesis test the company must be able to improve aspects of effectiveness in innovating in order to improve the performance of startup companies.

up.

\section{REFERENCES}

[1] Salamzadeh, Aidin. "Startup Companies- Life Cycle and Challenges Startup Companies: Life Cycle and Challenges Aidin Salamzadeh ( Corresponding Author ) Faculty of Entrepreneurship , University of Tehran , 16th Street, North Kargar Hiroko Kawamorita Kesim Faculty of Enginee." 4th International Conference on Employment, Education and Entrepreneurship (EEE), no. 2015, doi:10.13140/RG.2.1.3624.8167.

[2] Akram, Kashif, et al. "Role of Knowledge Management to Bring Innovation : An Integrated Approach." International Bulletin of Business Research, vol. 11, no. 11, 2011, pp. 121-34, doi:10.1055/s-0034-

\footnotetext{
IJoASER,Volume 2,Issue 3, November,2019

DOI: 10.33648/ijoaser.v2i2.40

Copyriht: STAI Al-Furqan Makassar,Indonesia

Content License: CC-BY-SA
} 


\section{1.}

[3] Centobelli, Piera, et al. "Knowledge Management in Startups: Systematic Literature Review and Future Research Agenda." Sustainability (Switzerland), vol. 9, no. 3, 2017, pp. 1-19, doi:10.3390/su9030361.

[4] Laskar, Sufia Kamal, and Dr. N. Anuradh. Rajaprabhu. "Substantive Incubation for Growth and Its Ict Impact on Msme'S." International Journal of Business \& Management, vol. IV, no. 4, 2016, pp. 53-77, doi:10.20472/BM.2016.4.4.003.

[5] Lin, Dechang, et al. "Improving Business Incubator Service Performance in China: The Role of Networking Resources and Capabilities." Service Industries Journal, vol. 32, no. 13, 2012, pp. 2091-114, doi:10.1080/02642069.2011.582498.

[6] Lin, Hsiu-Fen. "Marketing Strategies for Mediterranean Wineries Competitiveness the Case of Pantelleria." Quality - Access to Success, vol. 14, no. 137, 2013, pp. 101-06, doi:10.1108/01437720710755272.

[7] Macintosh, A. N. N., et al. "Knowledge Management Techniques: Teaching and Dissemination Concepts: J. Human-Computer Studies (1999) 51, 549-566." International Journal of Human-Computer Studies, vol. 51, no. 6, 1999, pp. 1174-89, http:/www.sciencedirect.com/science/article/B6WGR-45V7WG28/2/8331ff51f0a84515026a97c4186ecb97.

[8] Mardi Arya Jaya, Ridi Ferdiana, Silmi Fauziati. ANALISIS FAKTOR KEBERHASILAN STARTUP DIGITAL DI YOGYAKARTA Mardi Arya Jaya 1, Ridi Ferdiana 2 , Silmi Fauziati 3. 2017, pp. 167-73.

[9] Nathasya, Sri, and $\mathrm{Br}$ Sitepu. PENGARUH FAKTOR INTERNAL TERHADAP KEBERHASILAN START-UP BISNIS Di KOTA SURABAYA. no. 1, 2017, pp. 37-50.

[10] Voisey, Pam, et al. "The Measurement of Success in a Business Incubation Project." Journal of Small Business and Enterprise Development, vol. 13, no. 3, 2006, pp. 454-68, doi:10.1108/14626000610680307.

[11] Zohoori, Mahmood, et al. "The Relationship between Knowledge Sharing and Innovation in Electronic Industry of Iran." Journal of Small Business and Entrepreneurship Development, vol. 1, no. 1, 2013, pp. 26-33.

[12] Plessis, M. Du. "The Role of Knowledge Management in Innovation." Journal of Knowledge Management, vol. 11, no. 4, 2007, pp. 20-29, doi:10.1108/13673270710762684

[13] IMAMOGLU, Salih Zeki, et al. "The Relationship Between Organizational Learning and Firm Performance: The Mediating Roles of Innovation and Tqm." Journal of Global Strategic Management, vol. 1, no. 5, 2011, pp. 72-72, doi:10.20460/JGSM.2011515814. 
[14] Dutta, Sameeksha, Niveditha S Vishwamithra, Manvendra Singh Rathore. IMPORTANCE OF INCUBATION CENTRES WITH REFERENCE TO INDIAN STARTUP SCENARIO. 2016, pp. 16-19.

[15] Aaboen, Lise, et al. "Corporate Governance and Performance of Small High-Tech Firms in Sweden." Technovation, vol. 26, no. 8, 2006, pp. 955-68, doi:10.1016/j.technovation.2005.07.004.

[16] Adegbite, Oyeyemi. Business Incubators and Small Enterprise Development: The Nigerian Experience. no. July 2000, 2001, pp. 157 66.

[17] Al-Mubaraki, Hanadi Mubarak, et al. "The Road Map of International Business Incubation Performance." Journal of International Business and Cultural Studies, vol. 6, 2012, pp. 1-15, http://www.aabri.com/copyright.html.

[18] Almakenzi, Sara, et al. "A Survivability Model for Saudi ICT Startups." International Journal of Computer Science and Information Technology, vol. 7, no. 2, 2015, pp. 145-57, doi:10.5121/ijcsit.2015.7213.

[19] Ayatse, Fidelis A., et al. "Business Incubation Process and Firm Performance: An Empirical Review." Journal of Global Entrepreneurship Research, vol. 7, no. 1, Journal of Global Entrepreneurship Research, 2017, doi:10.1186/s40497-016-0059-6. 